\title{
A REVIEW OF GEODETIC DATUMS OF NEPAL AND TRANSFORMATION PARAMETERS FOR WGS84 TO GEODETIC DATUM OF NEPAL
}

\author{
Niraj Manandhar
}

Keywords: WGS84, Everest 1830, ENTMP, WNTMP, Transformation Parameter, Datum, GPS.

\begin{abstract}
In Nepal there exist different coordinate systems based on different geodetic datum. The existence of these datum and coordinate systems are poorly known. In this literature the geodetic datum that is in existence in one way or other are illustrated and discussed. The next common problem encountered by users is the availability of authentic precise transformation parameter between National geodetic datum and World Geodetic Datum 1984 (WGS84) ; global datum used by global positioning system (GPS). There can exist a considerable difference in the position between local and the global system and the difference could be of several hundred meters.
\end{abstract}

Based on the availability of data three sets of transformation parameters has been determined. The tests have been carried out to evaluate the accuracy of the transformation parameter in this region. The transformation parameter is recommended to transform the topographical data base of scale 1: 3500 and smaller. The accuracy of the transformation parameters are specified and can be used accordingly. This study will ultimately provide standardization and ease in transforming the coordinates from global datum (WGS84) to national geodetic datum of Nepal and vice versa.

\section{INTRODUCTION:}

The national and regional surveying and mapping works are all based on one single framework of geodetic control which is considered as a primary network of the country. The importance of the geodetic frame work for the country is beyond justification and is applied in almost all development works of the country such as defense, satellite lunching, missiles projecting etc, construction of major infrastructures of the country (dams, roads, sewerage system, irrigation, hydropower stations etc).

The concept of the position defined by co-ordinate system is the most essential part in the process of map-making and to the performance of the spatial search and analysis of geographic information. In order to plot the geographical feature on the map it is necessary to define the position of points on the features with respect to a common frame of reference or the co-ordinate system in other words.

In the other hand all the observations and measurements for accurate mapping are carried out on the physical surface of the earth where as computations and representation of the earth surface into paper in the form of map requires mathematical figure of the earth. In order words there has to have some relationship between the mathematical earth (ellipsoid) and the physical earth (geoid). In the geodetic terms we need to define best fitting ellipsoid and geoid. The best fitting ellipsoid is that particular ellipsoid which best fits the spread of the earth surface of a particular country. Therefore there are different ellipsoids of different country and hence different countries have different origin and different datum defined by certain parameters.

\section{GEODETIC DATUM:}

Precise positioning of points on the surface of the earth is one of the fundamental goal of geodesy. In order to define such point a starting point with respect to the reference system and a reference ellipsoid is necessary. The primary or the first order network is defined by means of well defined three-dimensional reference system of co-ordinates related to the earth fixed reference system. Such a reference system is defined by the dimension of the reference ellipsoid in terms of five parameters such as semi-major axis 'a' and flattening ' $\mathrm{f}$ ' and its position represented by regional $\mathrm{X}, \mathrm{Y}, \mathrm{Z}$ or $\varphi, \lambda, \mathrm{h}$ system specifying the 
orientation with respect to the global system, hence with respect to earth or geoid.

Usually the centre of the ellipsoid does not coincide with the earth's centre of mass but that axis is made parallel to the earth's axis of rotation with a pre assumption that global $\mathrm{Xg}, \mathrm{Yg}, \mathrm{Zg}$ rectangular coordinate system, has the origin which lies on the earth's centre of mass and a $\mathrm{Z}$ axis coinciding with the mean rotating axis of the earth, $X$ - axis passing through the mean of the Greenwich Meridian. The Y axis as defined by the plane which is perpendicular to $\mathrm{X}$ and $\mathrm{Z}$ - axis (Torge, 1991, pl 38).

\section{NATIONAL GEODETIC DATUM (NEPAL DATUM):}

In Nepal different geodetic datums have been used in different times for mapping purpose. The table 1 below shows the difference between them.

Table 1: Comparison of datums of Nepal

\begin{tabular}{|c|c|c|c|c|}
\hline Datum & India & $\begin{array}{c}\text { MODU } \\
\text { K }\end{array}$ & ENTMP & WGS84 \\
\hline Source & $\begin{array}{l}\text { Sources of } \\
\text { India }\end{array}$ & $\begin{array}{c}\text { MODU } \\
\text { K }\end{array}$ & $\begin{array}{c}\text { ENMP } \\
\text { project } \\
\text { report }\end{array}$ & $\begin{array}{c}\text { SDN \& } \\
\text { University } \\
\text { of } \\
\text { Colorado }\end{array}$ \\
\hline $\begin{array}{l}\text { Ref. } \\
\text { Spheroid }\end{array}$ & $\begin{array}{c}\text { Everest } \\
1830\end{array}$ & $\begin{array}{c}\text { Everest } \\
1830\end{array}$ & $\begin{array}{c}\text { Everest } \\
1830\end{array}$ & WGS84 \\
\hline $\begin{array}{l}\text { a (semi- } \\
\text { major } \\
\text { axis) }\end{array}$ & $\begin{array}{c}20922931.8 \\
0 \mathrm{ft} .\end{array}$ & $\begin{array}{c}6377 \\
276.345 \\
\mathrm{~m}\end{array}$ & $\begin{array}{c}6377 \\
276.345 \\
\mathrm{~m}\end{array}$ & $\begin{array}{c}6378 \\
137.00 \mathrm{~m}\end{array}$ \\
\hline $\begin{array}{l}1 / \mathrm{f} \\
\text { (flattening } \\
\text { ) }\end{array}$ & 300.8017 & 300.8017 & $\begin{array}{c}300.801 \\
7\end{array}$ & $\begin{array}{c}298.257223 \\
5\end{array}$ \\
\hline $\begin{array}{l}\text { Origin } \\
\text { latitude } \\
(\theta)\end{array}$ & $\begin{array}{c}24^{0} 07^{\prime} \\
11^{\prime \prime} .26 \mathrm{~N}\end{array}$ & $\begin{array}{c}27^{0} 41^{\prime} \\
31^{\prime \prime} .04 \mathrm{~N}\end{array}$ & $\begin{array}{c}27^{0} 41^{\prime} \\
32^{\prime \prime} .956 \\
\mathrm{~N}\end{array}$ & $\begin{array}{c}27^{0} 41^{\prime} \\
33^{\prime \prime} .778 \mathrm{~N}\end{array}$ \\
\hline $\begin{array}{l}\text { Origin } \\
\text { Longitude } \\
(\lambda)\end{array}$ & $\begin{array}{c}77^{0} 39^{\prime} \\
17^{\prime \prime} .576 \mathrm{E}\end{array}$ & $\begin{array}{c}85^{0} 31^{\prime} \\
20^{\prime \prime} .23 \mathrm{E}\end{array}$ & $\begin{array}{c}85^{0} 31^{\prime} \\
24^{\prime \prime} .941 \\
\mathrm{E}\end{array}$ & $\begin{array}{c}85^{0} 31^{\prime} \\
16^{\prime \prime} .384 \mathrm{E}\end{array}$ \\
\hline $\begin{array}{l}\text { Deflection } \\
\text { of }(\xi) \text { in } \\
\text { meridian }\end{array}$ & $-0 " .29$ & -37".03 & -37".03 & - \\
\hline $\begin{array}{l}\text { Deflection } \\
\text { in } \mathrm{P} \text {. } \\
\text { vertical }\end{array}$ & $2 " .28$ & $-21 " .57$ & $21 " .57$ & - \\
\hline $\begin{array}{l}\text { Separation } \\
\text { (N) }\end{array}$ & 0 & 0 & 0 & - \\
\hline
\end{tabular}

From the Table 1 it is obvious that there exists four different sets of co-ordinates on four different datum. The transformation parameters between these datum has to be established.

\section{GPS OBSERVATION IN NEPAL:}

In co-operation with University of Colorado and Massachusetts Institute of technology established the precise Global Positioning System (GPS) Geodetic network throughout the country.

The objective of establishing precise GPS geodetic network was:

- To provide a precise control grid for the geodetic survey throughout the country and

- To establish large scale strain grid to measure the north-south shortening, east-west extension and quantifying the uplift of the terrain across the Himalayan collision zone (Bilham \& Jackson, 1991)

The best co-ordinate values in WGS 84 reference system for station related to Nagarkot were determined from a network solution of all stations. The network consist of 28 precise GPS controls.

\section{ENTMP AND WNTMP GPS OBSERVATION:}

The Eastern Nepal Topographical Mapping Project ENTMP \& Western Nepal Topographic Mapping Project WNTMP was launched in order to produce new topographical map series of the country.

Geodetic controls over the project area was established by using the static relative GPS survey. In ENTMP a total of 101 stations were established and observed, the network consisting of 29 primary stations and 72 secondary stations. Instruments used for this field survey were Astech LD-XII GPS receivers. These instruments are 12 channel and dual frequency receivers.

In case of Western Nepal the ground control survey was carried out in two parts. First part was completed during January- April 1996 and second part during September - November 1996. During the first part 62 and during the second part 65 ground control GPS stations were monumented premarked and observed. Among them 51 were the primary stations and 76 were the secondary stations.

One session per day was observed using four to eight GPS satellites. The length of the observation session was 180 minutes in the primary network. Carrier phase observation of GPS satellites were processed using L2 corrected L1 phase measurements and double differences phase observations. Astech Inc's 
Geodetic post-processing software (GPPS), version 4.4.01 was used for the data processing. The adjustment of the network was done by using in FILNET (version 3.0.00) adjustment program.

One sigma accuracy of the baselines in the Network is better than 1-5 ppm.

\section{DATUM PARAMETERS:}

TRANSFORMATION

The present study is focused on the estimation of transformation parameters between Everest and WGS-84 in order to transform the digital data of the topographical maps or the ground control points (GCP).

The topographical mapping project was launched in order to update the topographical maps of the country. The topographical maps of Nepal are prepared and published in two parts. One of the Eastern Nepal and other of the Western Nepal. In both cases geodetic control was done by GPS/GNSS survey. As the main aim of the project was to provide control for the topographical mapping, it was felt important to transform GPS control from WGS84 to local datum. It was found that the distribution of common points has a good network geometry for transformation. Hence for the derivation of the seven parameter transformation controls considered from ENTMP and WNTMP was given considerable weight.

Similarly, in the process of the determination of the transformation parameter of WNTMP, 22 collocated points (the common points between the reference frame i.e. WGS-84 and Everest 1830) first order points based on Nepal datum were used.

In the computation of transformation parameter 3dimentional coordinates based on WGS-84 were taken as the controls established by WNTMP and ENTMP. This network consists of all together 80 primary stations and 148 secondary stations. A total of 33 primary GPS points were common stations in first order geodetic network of Nepal. These 33 stations are used for the derivation of the transformation parameter. 33 stations of first order network of Nepal based on Nepal datum were obtained from appendix (1) report of Ministry of Defense United Kingdom (MODUK). The Bursa-Wolf method was used to estimate the transformation parameter.

The values of the transformation (WGS-84 to Everest1830) parameters are as follows:
Table 2

\begin{tabular}{|c|c|}
\hline Parameters & $\begin{array}{c}\text { Estimated } \\
\text { Values }\end{array}$ \\
\hline Translation in $\mathrm{X}$ axis(m) & 124.3813 \\
\hline Translation in $\mathrm{Y}$ axis (m) & -521.6700 \\
\hline Translation in $\mathrm{Z}$ axis (m) & -764.5137 \\
\hline Rotation in $\mathrm{X}$ axis (Sec) & -17.1488 \\
\hline Rotation in $\mathrm{Y}$ axis (Sec) & 8.11536 \\
\hline Rotation in $\mathrm{Z}$ axis (Sec) & -11.1842 \\
\hline Scale factor (ppm) & 2.1105 \\
\hline
\end{tabular}

In order to test the accuracy of the transformation parameter given in table 2 the second and third order coordinates in WGS-84 were transformed to Nepal datum. Then the transformed coordinates were compared with existing second and third order coordinates of the same points.

As in the previous test, the deviations between same particular points were quantified by computing the distance using the set of coordinates of the same points. Maximum and minimum difference between $\mathrm{X}$ and $\mathrm{Y}$ co-ordinates were computed along with distance between two points. The results are tabulated in table 3.

The variations in the second and third order Transformed coordinates and National coordinates are presented below:

Table 3

\begin{tabular}{|l|c|c|c|}
\hline & $\begin{array}{c}\text { Difference in } \\
\mathbf{X} \\
\text { coordinates( } \\
\mathbf{\Delta X})\end{array}$ & $\begin{array}{c}\text { Difference in } \\
\mathbf{Y} \\
\text { coordinates( } \\
\mathbf{\Delta Y})\end{array}$ & $\begin{array}{c}\text { Distance } \\
\text { between the } \\
\text { points }\end{array}$ \\
\hline $\begin{array}{l}\text { Maximu } \\
\text { m Value } \\
\text { in (m) }\end{array}$ & 1.0717 & 2.7447 & $\mathbf{2 . 7 7 3 7}$ \\
\hline $\begin{array}{l}\text { Minimun } \\
\text { Value in } \\
\text { (m) }\end{array}$ & -0.5733 & -1.828 & 0.077912 \\
\hline Average & & & 0.872848 \\
\hline
\end{tabular}

Referring table 3 the average deviation between the transformed points are found to be $0.872 \mathrm{~m}$ therefore this parameter can be used in the map of scale 1:3500 or smaller. 
The values of the transformation (Everest1830 to WGS-84 ) parameters are as follows:

Table 4

\begin{tabular}{|l|c|}
\hline \multicolumn{1}{|c|}{ Parameters } & Estimated Values \\
\hline Translation in X axis(m) & -124.3813 \\
\hline Translation in Y axis (m) & 521.6700 \\
\hline Translation in Z axis (m) & 764.5137 \\
\hline Rotation in X axis (Sec) & 17.1488 \\
\hline Rotation in Y axis (Sec) & -8.11536 \\
\hline Rotation in Z axis (Sec) & 11.1842 \\
\hline Scale factor (ppm) & -2.1105 \\
\hline
\end{tabular}

Comparison of Transformed coordinates from Everest Spheroid to WGS 84 Ellipsoid using parameters of table 4 is shown in table 5 .

Table 5

\begin{tabular}{|c|c|c|c|c|}
\hline $\begin{array}{l}\text { Station } \\
\text { Name }\end{array}$ & & $\begin{array}{c}\text { Everest } \\
\text { Spheroid } \\
\text { Coordin } \\
\text { ate }\end{array}$ & $\begin{array}{c}\text { WGS } 84 \\
\text { Coordinat } \\
\text { e }\end{array}$ & $\begin{array}{c}\text { Transforme } \\
\text { d } \\
\text { Coordinate } \\
\text { from } \\
\text { Everest to } \\
\text { WGS 84 } \\
\text { Using } \\
\text { Parameter }\end{array}$ \\
\hline \multirow{2}{*}{$\begin{array}{l}\text { Sirancho } \\
\mathrm{k}\end{array}$} & Lat. & $\begin{array}{l}2805 \\
01.38\end{array}$ & $\begin{array}{l}2805 \\
02.58\end{array}$ & 280502.592 \\
\hline & Lon. & $\begin{array}{l}8436 \\
11.00\end{array}$ & $\begin{array}{l}8436 \\
2.719\end{array}$ & 843602.715 \\
\hline \multirow{2}{*}{$\begin{array}{l}\text { Chaure } \\
\text { dada }\end{array}$} & Lat. & $\begin{array}{l}2726 \\
27.85\end{array}$ & $\begin{array}{l}2726 \\
29.28\end{array}$ & 272629.293 \\
\hline & Lon. & $\begin{array}{l}8448 \\
44.45\end{array}$ & $\begin{array}{c}8448 \\
36.117\end{array}$ & 844836.129 \\
\hline \multirow{2}{*}{ Dhaje } & Lat. & $\begin{array}{l}2651 \\
56.88\end{array}$ & $\begin{array}{l}2651 \\
58.66\end{array}$ & 265158.70 \\
\hline & Lon. & $\begin{array}{l}8436 \\
11.00\end{array}$ & $\begin{array}{l}8436 \\
2.719\end{array}$ & 843602.760 \\
\hline \multirow{2}{*}{$\begin{array}{l}\text { Laure } \\
\text { Dada }\end{array}$} & Lat. & $\begin{array}{c}2722 \\
19.7400\end{array}$ & $\begin{array}{l}2722 \\
21.33\end{array}$ & 272221.365 \\
\hline & Lon. & $\begin{array}{c}8655 \\
20.7600\end{array}$ & $\begin{array}{l}8655 \\
11.43\end{array}$ & 865511.422 \\
\hline \multirow{2}{*}{$\begin{array}{l}\text { Biratnaga } \\
\mathrm{r}\end{array}$} & Lat. & $\begin{array}{l}2629 \\
00.94\end{array}$ & $\begin{array}{c}2629 \\
02.846\end{array}$ & 262902.891 \\
\hline & Lon. & $\begin{array}{ll}8716 \\
01.17\end{array}$ & $\begin{array}{c}8715 \\
51.742\end{array}$ & 871551.764 \\
\hline
\end{tabular}

7. CONCLUSION AND RECOMMENDATION:
It has been felt essential that the integration of the coordinates of first, second, third, and lower order triangulation points in National Geodetic datum is essential to bring homogeneity in co-ordinate system of country.

The relationship between Nepal datum and WGS-84 co-ordinates is of immense requirement in present context. In order to bring the uniformity and consistency in coordinate conversion it is very important to determine reliable transformation parameters.

Transformation parameter which has been determined is recommended to use as a National Transformation Parameter of the whole country. These parameters can be used for scales 1: 3500 and smaller.

\section{References:}

Geodesy, G. Bomford $3^{\text {rd }}$ Edition.

Military Engineering Vol. XIII- Part VI, Survey Computations 1978.

Manandhar, N. (1997) Study Report on Geodetic Datums, Transformation between the Reference System and Height Datum in Nepal, Survey Department, Geodetic Survey Branch (Unpublished). Manandhar, N. (1997) The Geoid Studies in Nepal, M.Sc thesis, University of New South Wales, Australia.

R.R. Chhatkuli, S.M. Shrestha, N. Manandhar (2003), Transformation of Datum and Projection of Spatial data in GIS Application in the context of NGII in Nepal. National Convention and FEISCA Regional Meet.

Report of Ground Control Survey, Eastern Nepal Topographical Mapping Project, Survey Department. Final Report of Ground Control Surveys, Vol.I, Vol.II, Vol.III Western Nepal Topographical Mapping Project, Survey Department.

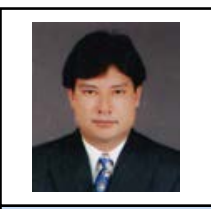

\section{Author's Information}

Name: Mr. Niraj Manandhar

Academic Qualification: ME in Geomatic Engineering

Organization: Survey Department Current Designation: Chief Survey Officer Work Experience: 34 years Published Papers/Articles: Ten e-mail: manandhar_niraj@hotmail.com 